\title{
MIR1-2 Gene
}

National Cancer Institute

\section{Source}

National Cancer Institute. MIR1-2 Gene. NCI Thesaurus. Code C80730.

This gene is involved in the regulation of gene expression and plays a role in the development of cardiomyopathy. 